\title{
ASI eksklusif dan berat lahir berpengaruh terhadap stunting pada balita 2-5 tahun di Kabupaten Pesawaran
}

\author{
Exclusive breastfeeding and birth weight have an effect on stunting in children 2-5 years in Pesawaran Regency
}

\author{
Apri Sulistianingsih', Rita Sari \\ ${ }^{1}$ Program Studi DIII Kebidanan STIKes Muhammadiyah Pringsewu \\ ${ }^{2}$ Program Studi Ners STIKes Muhammadiyah Pringsewu
}

\begin{abstract}
Background: Stunting cases in infants in Indonesia continue to be a maternal and child health problem. Stunting cases in Pesawaran District increase every year. Some of the factors that influence the incidence of stunting in children include the history of exclusive breastfeeding and low birth weight (LBW). Objective: This study aims to determine the effect of exclusive breastfeeding and birth weight on stunting in children 2-5 years cases in the Pesawaran District. Method: This research used observational analytics with a cross-sectional approach. This research was conducted in March-May 2017 in 12 Puskesmas on Pesawaran Lampung District. The number of samples was 385 samples. The variables studied in this study were the incidence of stunting, history of $L B W$ and history of exclusive breastfeeding. Analysis and present data using the Chi-Square test and multiple logistic regression. Results: Children with a history of $L B W(O R=12.30 ; 95 \%$ CI:3.663-41.299) and exclusive breastfeeding history (OR=0.122; 95\% CI:0.075-0.199) were significantly associated with the incidence of stunting. The multivariate analysis explained the history of exclusive breastfeeding with $O R=0.108$ (CI 95\%: 0.065-0.180) and birth weight with OR=17.063 (CI 95\%: 4.892-59.511). Conclusion: Children with exclusively breastfeeding 9.3 times less risk for stunting than children non-exclusive breastfeeding or exclusive breastfeeding provides a protective effect against stunting in children 2-5 years. Children with an LBW history had a risk of 17.063 times greater for stunting than children with normal birth weight.
\end{abstract}

KEY WORDS: exclusive breastfeeding; LBW; stunting

\begin{abstract}
ABSTRAK
Latar belakang: Kasus stunting pada balita di Indonesia masih menjadi masalah kesehatan ibu dan anak. Kasus stunting di Kabupaten Pesawaran meningkat setiap tahunnya. Beberapa faktor yang mempengaruhi kejadian stunting pada balita diantaranya adalah riwayat ASI eksklusif dan bayi berat lahir rendah (BBLR). Tujuan: Penelitian ini bertujuan untuk mengetahui pengaruh ASI eksklusif dan berat lahir terhadap stunting pada balita 2-5 tahun di Kabupaten Pesawaran. Metode: Penelitian observasional analitik dengan pendekatan cross-sectional yang dilaksanakan pada Maret-Mei 2017 di 12 Puskesmas Kabupaten Pesawaran Lampung dan jumlah sampel sebanyak 385 sampel. Variabel yang diteliti adalah kejadian stunting, riwayat BBLR, dan riwayat ASI eksklusif. Analisis data menggunakan uji Chi-Square dan regresi logistik ganda. Hasil: Balita dengan riwayat BBLR (OR=12,30; CI 95\%:3,663-41,299) dan riwayat ASI eksklusif (OR=0,122; CI 0,075-0,199) berhubungan signifikan dengan kejadian stunting pada balita 2-5 tahun. Demikian juga dengan hasil analisis multivariat yaitu riwayat ASI eksklusif dengan nilai OR=0,108 (CI 95\%: 0,065-0,180) dan berat lahir dengan nilai OR=17,063 (CI 95\%: 4,892-59,511). Simpulan: Balita yang memperoleh ASI eksklusif berisiko 9,3 kali lebih kecil untuk terjadi stunting dibandingkan balita yang tidak memperoleh ASI eksklusif atau ASI eksklusif memberikan efek proteksi terhadap terjadinya stunting pada balita. Sebaliknya, pada berat bayi lahir, ditemukan bahwa balita dengan riwayat BBLR berisiko 17,063 kali lebih besar untuk mengalami stunting dibandingkan balita dengan riwayat berat lahir normal.
\end{abstract}

KATA KUNCI: ASI eksklusif; BBLR; stunting

Korespondensi: Apri Sulistianingsih, STIKes Muhammadiyah Pringsewu, Jl. Makam KH. Ghalib No.112, Pringsewu Utara, Kec. Pringsewu, Kabupaten Pringsewu, Lampung 35373, Indonesia, Telp. 0822-8021-9225, e-mail: sulistianingsih.apri@gmail.com 


\section{PENDAHULUAN}

Secara global, diperkirakan $26 \%$ balita mengalami stunting (1). Menurut data riset kesehatan dasar (Riskesdas) tahun 2013, kasus balita pendek (stunting) di Indonesia sebesar 37,2\% sedangkan prevalensi di Provinsi Lampung yaitu sebesar 42,6\% (2). Bahkan, prevalensi balita pendek di Kabupaten Pesawaran mencapai 50,81\%. Menurut laporan pemantauan status gizi (PSG) tahun 2015, kejadian balita pendek di Kabupaten Pesawaran sebesar 24,4\% yang mengalami peningkatan menjadi $26,7 \%$ pada tahun 2016 dan $35,5 \%$ pada tahun 2017 (3-5).

Balita pendek (stunting) merupakan suatu kondisi kekurangan gizi kronis yang dimulai sejak 1000 hari pertama kehidupan (1). Pada kajian penelitian sebelumnya, bayi berat lahir rendah (BBLR), riwayat air susu ibu (ASI) eksklusif, dan prematuritas merupakan faktor yang berhubungan dengan stunting di Indonesia $(1,6)$. Dampak dari stunting dapat mempengaruhi keterlambatan dalam berpikir dan perkembangan pada masa balita hingga berdampak pada masa dewasa dengan membatasi kapasitas kerja karena berkurangnya massa otot dan meningkatkan risiko obstetri pada wanita (7).

Berat lahir berpengaruh terhadap pertumbuhan dan perkembangan di masa yang akan datang (8). Kasus BBLR di Indonesia mencapai 10\% (2) sedangkan di Kabupaten Pesawaran, BBLR pada tahun 2016 sebanyak 7,9\% (8). Bayi dengan BBLR akan mengalami gangguan pertumbuhan karena risiko komplikasi pada masa kelahirannya. Hasil kajian pada studi sebelumnya menjelaskan bahwa anak-anak dengan berat badan lebih dari 3000 gram berisiko lebih rendah untuk menjadi stunting (OR=0,25; CI 95\%:0,11-0,54) (7). Penelitian menunjukkan bahwa bayi BBLR memiliki cadangan gizi mikro untuk pertumbuhan yang rendah seperti vitamin A, seng, dan zat besi sehingga sangat bergantung pada ASI untuk menutupi kekurangan gizi (9). Namun, di sisi lain ternyata cakupan ASI di Indonesia masih rendah. Data saat ini menunjukkan bahwa hanya $27,1 \%$ penduduk Indonesia yang menyusui secara eksklusif. Persentase cakupan pemberian ASI eksklusif di Kabupaten Pesawaran tahun 2016 masih rendah yaitu 49,7\%. Hasil studi sebelumnya menyatakan bahwa durasi menyusui dan durasi pemberian ASI eksklusif secara signifikan memengaruhi terjadinya stunting. Tingkat keparahan stunting menunjukkan kecenderungan menurun pada anak yang diberikan ASI eksklusif (10).

Kabupaten Pesawaran merupakan kabupaten yang tergolong baru karena diresmikan pada tahun 2007 . Selama 10 tahun pemerintahan, belum banyak penelitian terkait dengan faktor penyebab stunting di Kabupaten Pesawaran, terutama yang berkaitan dengan BBLR dan ASI eksklusif. Padahal prevalensi balita stunting cukup tinggi dan meningkat setiap tahunnya. Berdasarkan data tersebut menunjukkan bahwa prevalensi stunting di Kabupaten Pesawaran masih menjadi masalah. Dengan demikian, tujuan dari penelitian ini adalah untuk menganalisis pengaruh faktor ASI eksklusif dan berat lahir terhadap kejadian stunting pada balita 2-5 tahun di Kabupaten Pesawaran.

\section{BAHAN DAN METODE}

Penelitian ini adalah penelitian kuantitatif observasional analitik dengan pendekatan cross-sectional yang dilaksanakan pada bulan Maret-Mei 2017 di 12 Puskesmas Kabupaten Pesawaran Lampung. Populasi penelitian ini adalah pasangan ibu dan anak balita yang berada di 12 wilayah Puskesmas Pesawaran. Besar sampel ditentukan dengan menggunakan rumus uji beda dua proporsi yang diperoleh sebanyak 385 sampel. Metode sampling yang digunakan adalah proportional cluster sampling untuk 12 Puskesmas. Setiap puskesmas diambil datanya sesuai dengan jumlah balita yang terdaftar di wilayah kerja Puskesmas Pesawaran kemudian jumlah balita tersebut dibagi sesuai dengan jumlah sampel yaitu 385 subjek. Kriteria inklusi yang ditetapkan pada penelitian ini adalah ibu dan balita usia 2-5 tahun yang berada di 12 wilayah Puskesmas Pesawaran dan bersedia menjadi subjek penelitian. Sementara itu, kriteria eksklusi pada penelitian ini adalah balita dengan riwayat cacat bawaan dan menderita penyakit serius pada saat penelitian.

Variabel yang diteliti adalah kejadian stunting pada balita sebagai variabel dependen serta riwayat BBLR dan riwayat ASI eksklusif sebagai variabel independen. Variabel stunting merupakan hasil pengukuran tinggi badan menurut umur (TB/U) yaitu apabila nilai $z$ score kurang dari -2 (z score $\mathrm{TB} / \mathrm{U}<-2 \mathrm{SD})$ sedangkan nilai 
$z$ score lebih dari atau sama dengan -2 ( $z$ score TB/ $\mathrm{U} \geq-2 \mathrm{SD}$ ) dikategorikan normal (1). Variabel riwayat BBLR diketahui dari catatan riwayat persalinan di buku Kesehatan Ibu dan Anak (KIA) dengan kategori BBLR jika berat badan lahir kurang dari 2.500 gram (1). Variabel riwayat ASI eksklusif diketahui melalui wawancara individu menggunakan kuesioner Riset Kesehatan Dasar (2013). Bayi yang tidak diberikan makanan atau minuman selain ASI sejak lahir sampai dengan usia 6 bulan maka dikategorikan ASI eksklusif sedangkan apabila bayi diberikan makanan sebelum mulai disusui atau diberikan makanan selain ASI sebelum usia 6 bulan maka dikategorikan tidak ASI eksklusif (2).

Proses penelitian diawali dengan melakukan survei catatan balita di puskesmas dan desa termasuk data balita yang tidak aktif di posyandu, kemudian peneliti melakukan sampling sesuai teknik yang telah ditentukan. Peneliti memberikan penjelasan kepada subjek penelitian tentang tata cara dan etika penelitian kemudian dilanjutkan dengan penandatangan surat kesediaan menjadi responden. Proses pengambilan data dilakukan oleh peneliti beserta enumerator. Enumerator merupakan bidan puskesmas yang bertugas di wilayah binaan dengan minimal pendidikan diploma tiga. Wawancara dan pengukuran tinggi badan anak untuk

Tabel 1. Karakteritik responden

\begin{tabular}{lcc}
\hline \multicolumn{1}{c}{ Variabel } & n & \% \\
\hline Pendidikan orang tua & & \\
$\quad$ Dasar (SD/SMP) & 127 & 33,0 \\
$\quad$ Menengah/tinggi & 258 & 67,0 \\
Penghasilan orang tua & & \\
$\quad$ <UMR & 198 & 51,4 \\
$\quad$ UUMR & 187 & 48,6 \\
Makanan prelaktal & & \\
Ya & 179 & 46,5 \\
Tidak & 206 & 53,5 \\
Usia mulai diberikan makanan selain ASI & \\
$\quad<6$ bulan & 225 & 66,2 \\
$\quad$ 6 bulan & 130 & 33,8 \\
Jenis makanan selain ASI yang pertama kali diberikan \\
$\quad$ Susu formula & 67 & 17,4 \\
Bubur formula & 81 & 21,0 \\
Pisang dihaluskan & 75 & 19,5 \\
Bubur nasi & 89 & 23,1 \\
Lain-lain & 73 & 19,0 \\
\hline
\end{tabular}

menentukan status gizi dilakukan sebanyak 1 kali pengukuran. Analisis data menggunakan uji Chi-Square dan regresi logistik ganda.

\section{HASIL}

Karakteristik responden pada Tabel 1 menunjukkan bahwa sebagian besar pendidikan orang tua responden tergolong berpendidikan menengah/tinggi (65\%) dan penghasilan di atas Upah Minimum Regional (UMR) $(57,7 \%)$. Lebih lanjut, mayoritas responden tidak diberikan makanan prelaktal (53,5\%). Namun, mayoritas usia awal pemberian makanan selain ASI yaitu kurang dari 6 bulan $(66,7 \%)$ dengan jenis makanan yang pertama kali diberikan setelah ASI yang terbanyak secara berurutan adalah bubur nasi $(23,1 \%)$; bubur formula $(21,0 \%)$; pisang dihaluskan (19,5\%); dan lain-lain (19,0\%).

Berdasarkan hasil penelitian pada Tabel 2 diketahui bahwa dari 385 balita di 12 Puskesmas Kabupaten Pesawaran ditemukan balita pendek (stunting) sebanyak 46\% sedangkan balita normal sebanyak 54\%. Sebagian besar balita tidak mendapatkan ASI eksklusif (66,2\%) sedangkan balita yang memiliki riwayat ASI eksklusif hanya 33,8\%. Mayoritas balita memiliki berat lahir normal $(92,2 \%)$ sedangkan sejumlah kecil balita memiliki riwayat BBLR (7,8\%). Tabel 2 juga menunjukkan adanya hubungan antara riwayat ASI eksklusif dan berat lahir dengan kejadian stunting pada balita. Balita dengan riwayat ASI eksklusif berhubungan signifikan dengan kejadian stunting ( $\mathrm{p}<0,001$; OR=0,122; CI 95\%: 0,075$0,199)$. Demikian juga balita dengan riwayat BBLR $(\mathrm{p}<0,001 ; \mathrm{OR}=12,30$; CI 95\%: 3,663-41,299).

Hasil analisis pada Tabel 3 menunjukkan permodelan uji regresi ganda yaitu hasil riwayat ASI eksklusif dengan nilai OR=0,108 (CI 95\%: 0,0650,180 ) dan berat lahir dengan nilai $\mathrm{OR}=17,063$ (CI 95\%: 4,892-59,511). Hal ini menjelaskan bahwa balita yang memperoleh ASI eksklusif berisiko 9,3 kali lebih kecil untuk terjadinya stunting dibandingkan balita yang tidak memperoleh ASI eksklusif atau ASI eksklusif memberikan efek proteksi terhadap terjadinya stunting pada balita. Sebaliknya pada berat lahir, ditemukan bahwa balita dengan riwayat BBLR berisiko 17,063 kali lebih besar untuk mengalami stunting dibandingkan balita dengan riwayat berat lahir normal. 
Tabel 2. Hubungan riwayat ASI eksklusif dan berat lahir dengan stunting pada balita 2-5 tahun di Kabupaten Pesawaran

\begin{tabular}{|c|c|c|c|c|c|c|c|c|}
\hline \multirow{3}{*}{ Variabel } & \multicolumn{4}{|c|}{ Status gizi } & \multirow{2}{*}{\multicolumn{2}{|c|}{ Total }} & \multirow{3}{*}{$\mathbf{p}$} & \multirow{3}{*}{$\begin{array}{c}\text { OR } \\
\text { (CI 95\%) }\end{array}$} \\
\hline & \multicolumn{2}{|c|}{ Normal } & \multicolumn{2}{|c|}{ Stunting } & & & & \\
\hline & $\mathbf{n}$ & $\%$ & n & $\%$ & $\mathbf{n}$ & $\%$ & & \\
\hline \multicolumn{9}{|c|}{ Riwayat ASI eksklusif } \\
\hline ASI eksklusif & 29 & 22,3 & 101 & 77,7 & 130 & 33,8 & \multirow[t]{3}{*}{$<0,001$} & 0,122 \\
\hline Tidak eksklusif & 179 & 70,2 & 76 & 29,8 & 225 & 66,2 & & $(0,075-0,199)$ \\
\hline Total & 208 & 54,0 & 177 & 46,0 & 385 & 100 & & \\
\hline \multicolumn{9}{|l|}{ Berat lahir } \\
\hline Normal & 205 & 57,7 & 150 & 42,3 & 355 & 92,2 & \multirow[t]{3}{*}{$<0,001$} & 12,300 \\
\hline BBLR & 3 & 10,0 & 27 & 90,0 & 30 & 7,8 & & $(3,663-41,299)$ \\
\hline Total & 208 & 54,0 & 177 & 46,0 & 385 & 100 & & \\
\hline
\end{tabular}

Tabel 3. Analisis multivariat pengaruh riwayat ASI eksklusif dan berat lahir terhadap stunting pada balita 2-5 tahun di Kabupaten Pesawaran

\begin{tabular}{llllll}
\hline \multicolumn{1}{c}{ Variabel } & Koef $\mathbf{\beta}$ & SE (B) & p & POR*Adj & (CI 95\%) \\
\hline I. Model awal dan akhir & & & & & \\
Riwayat ASI eksklusif & $-2,222$ & 0,260 & $<0,001$ & 0,108 & $0,065-0,180$ \\
Berat lahir & 2,837 & 0,637 & $<0,001$ & 17,063 & $4,892-59,511$ \\
Konstanta & 1,142 & 0,213 & $<0,001$ & & \\
\hline
\end{tabular}

\section{BAHASAN}

Hasil penelitian ini menunjukkan bahwa kejadian stunting pada balita di Kabupaten Pesawaran masih tinggi yaitu sebesar $46 \%$ dari 385 balita yang menjadi subjek penelitian. Hasil ini masih lebih tinggi dibandingkan laporan Riskesdas (2013) di Provinsi Lampung yaitu 42,6\% dan laporan Pemantauan Status Gizi (PSG) di Kabupaten Pesawaran tahun 2017 yaitu 35,5\% (2,8). Stunting merupakan kasus pada balita yang memiliki tinggi badan dibandingkan usia dengan nilai z-skor kurang dari dua standar deviasi ( $<2 \mathrm{SD})$ di bawah median (11). Tinggi badan menurut umur diketahui sebagai salah satu indikator pertumbuhan pada masa balita. Tinggi badan menurut umur juga dapat menggambarkan kecukupan nutrisi pada masa balita. Balita yang tidak terpenuhi kebutuhan nutrisinya dapat berpengaruh terhadap pertumbuhan, perkembangan, dan kecerdasan. Apabila kondisi ini terus berlanjut maka akan berdampak pada daya saing yang rendah pada masa dewasa. Kejadian stunting juga berkaitan dengan beberapa faktor diantaranya adalah berat lahir, usia ibu, dan cakupan ASI eksklusif (7).

Tingginya kejadian stunting pada penelitian ini karena peneliti juga melakukan penelitian pada balita yang tidak rutin ke Posyandu di wilayah kerja 12 Puskesmas Kabupaten Pesawaran untuk mengukur tinggi badan dan berat badan. Menurut Buku Kesehatan Ibu dan Anak (KIA), pemantauan status gizi balita dapat dilihat dari pertumbuhan berat badan menurut umur, berat badan menurut tinggi badan, dan tinggi badan menurut umur. Pemantauan ini sebaiknya dilakukan setiap bulan dan dituliskan di dalam buku KIA. Namun pada kenyataannya, kader Posyandu hanya rutin mencatat pemantauan berat badan menurut umur, sedangkan kurva pemantauan tinggi badan menurut umur dan berat badan menurut umur belum menjadi agenda rutin pencatatan. Oleh karena itu, kasus stunting belum dapat dideteksi secara dini, padahal pada buku KIA telah terdapat kurva pemantauan yang terbagi berdasarkan umur 0-6 bulan, 6 bulan-2 tahun, dan 2-5 tahun yang seharusnya rutin dicatat setiap bulan (12).

Kasus riwayat BBLR pada penelitian ini ditemukan sebanyak 7,8\%. Prevalensi ini hampir sama dengan prevalensi di tingkat Provinsi Lampung yaitu $8 \%$ dan lebih rendah dari prevalensi nasional yaitu $10 \%$. Faktor risiko BBLR di Indonesia diantarnya adalah faktor lingkungan (paparan asap rokok dan tempat tinggal), 
sosiodemografi (usia dan sosio-ekonomi), dan faktor ibu (anemia, plasenta abnormal, status gizi ibu, pemeriksaan antenatal, pre-eklampsia, paritas, dan komplikasi pada kehamilan). Anemia dan status gizi menjadi faktor dominan yang mempengaruhi BBLR (11).

Pada penelitian ini diketahui adanya riwayat ASI eksklusif pada balita sebanyak 33,2\%. Cakupan pemberian ASI eksklusif secara nasional di Indonesia hanya 27,1\% (13). Rendahnya cakupan ASI eksklusif berdampak pada masih tingginya kasus malnutrisi di Indonesia. Hasil penelitian ini menunjukkan bahwa riwayat BBLR dan dan riwayat ASI eksklusif berpengaruh signifikan terhadap kejadian stunting di Kabupaten Pesawaran Lampung. Bayi berat lahir rendah merupakan faktor predisposisi pencapaian pertumbuhan setelah lahir. Bayi berat lahir rendah berhubungan dengan kelahiran prematur dan atau Intrauterine Growth Restriction (IUGR). Hasil studi membuktikan bahwa BBLR menjadi penentu utama terjadinya stunting (1). Retardasi pertumbuhan dini bersamaan dengan perkembangan kognitif yang kurang optimal dan terhambatnya pertumbuhan organ internal dapat mengakibatkan kemampuan kognitif yang rendah dan meningkatkan risiko penyakit kronis di kemudian hari (14).

Hasil penelitian ini didukung oleh studi di Amazon yang menunjukkan bahwa BBLR merupakan faktor determinan terjadinya stunting pada anak di bawah 5 tahun, kemudian disusul dengan riwayat infeksi kronis seperti diare (15). Selain itu, penelitian di Iran juga menjelaskan bahwa kasus BBLR dapat meningkatkan kejadian stunting pada balita (7). Bayi dengan BBLR akan mengalami gangguan pertumbuhan sejak awal kehidupannya. Stunting pada anak-anak, khususnya dalam 2 tahun pertama kehidupan memiliki efek jangka panjang pada tinggi badan saat dewasa, pencapaian sekolah, pendapatan, hingga kecenderungan penyakit kronis saat dewasa (16). Studi di Afrika juga menunjukkan bahwa balita yang mengalami stunting, akan berisiko mengalami gangguan ekonomi, gangguan reproduksi, dan penurunan kognitif pada masa dewasa (17).

Hasil analisis penelitian ini menunjukkan bahwa balita dengan riwayat ASI eksklusif dapat menurunkan risiko menjadi stunting sampai 9,3 kali lebih kecil dibandingkan pada balita tanpa riwayat ASI eksklusif.
Pemberian ASI eksklusif bersifat protektif terhadap kejadian stunting. Namun, pada jangka pendek, ASI eksklusif memberikan perlindungan pada infeksi diare dan pernapasan (18) yang telah banyak bukti bahwa infeksi berkepanjangan menyebabkan balita stunting. Pada jangka panjang, ASI eksklusif memberikan perlindungan terhadap penyakit tidak menular seperti diabetes, tekanan darah, dan kolestrol serta obesitas (19).

Menyusui adalah cara terbaik dalam menyediakan makanan yang ideal untuk pertumbuhan dan perkembangan bayi. Lebih dari dua pertiga angka kematian pada balita terkait dengan praktik pemberian makan yang tidak tepat selama tahun pertama kehidupan. Hasil studi pada Empowered Action Group (EAG) States di India menyatakan bahwa pemberian ASI eksklusif merupakan faktor utama yang mempengaruhi status gizi anak. Dengan demikian, intervensi tunggal yang paling hemat biaya untuk mengurangi kematian bayi di negara-negara berkembang adalah promosi pemberian ASI eksklusif (10).

Lebih lanjut, pemberian ASI dipengaruhi oleh faktor keluarga dan motivasi ibu. Sebagian besar kasus menunjukkan bahwa ibu yang menyusui juga mengalami kondisi kurang gizi, yang mengakibatkan rendahnya produksi ASI dan pada akhirnya dilakukan pengenalan makanan pendamping ASI (MP-ASI) kepada bayi sebelum berusia 6 bulan. Beberapa kajian penelitian juga menyatakan bahwa berat badan lahir, status menyusui, usia ibu, besar keluarga, status sosial ekonomi, dan urutan kelahiran berhubungan dengan kejadian stunting pada anak $(7,10,20)$. Hasil penelitian lain juga menyebutkan bahwa stunting secara signifikan terkait dengan status ekonomi miskin (21). Temuan ini sesuai dengan hipotesis umum bahwa kemiskinan mengarah pada asupan gizi yang kurang pada kehamilan yang dapat menyebabkan BBLR. Sementara itu, BBLR juga menyebabkan komplikasi pada masa kelahiran yang mengganggu pertumbuhan dan perkembangan sehingga menyebabkan stunting (15).

Keterbatasan dan kelemahan pada penelitian ini terletak pada desain penelitian cross-sectional yang kurang mampu untuk menjelaskan secara tepat hubungan riwayat ASI eksklusif dan BBLR dengan kejadian stunting. Penelitian ini tidak menganalisis faktor 
sosiodemografi yang menjadi latar belakang terjadinya kasus stunting. Penghasilan yang rendah cenderung memiliki variasi makan yang monoton seperti nabati, sayuran, dan buah yang mungkin terbatas dibandingkan dengan rumah tangga berpenghasilan lebih tinggi (20). Peneliti juga tidak melakukan eksplorasi terhadap pola makan yang merupakan faktor langsung penyebab kejadian stunting. Oleh karena itu, peneliti kemudian melakukan penggalian data tentang BBLR menggunakan riwayat kelahiran dalam buku KIA. Pada riwayat ASI eksklusif, peneliti melakukan pengkajian dengan menanyakan riwayat pemberian ASI termasuk makanan prelaktal, pendamping ASI, pemberian makanan lain, dan usia mulai diberikan makanan pendamping ASI.

Hasil dari studi ini membuktikan bahwa riwayat BBLR dan tidak memberikan ASI eksklusif merupakan faktor risiko stunting di Kabupaten Pesawaran. Menurut temuan peneliti, mengurangi kasus stunting membutuhkan upaya yang berkelanjutan, dimulai dari mendiagnosis dan mengobati ibu dan anak sejak masa prakonsepsi dan peningkatan praktik pemberian ASI eksklusif di antara ibu dan keluarga. Hasil penelitian ini dapat menjadi pertimbangan bagi pemegang kebijakan untuk meningkatkan intervensi dalam promosi ASI eksklusif dan meningkatkan cakupan ASI eksklusif di Kabupaten Pesawaran. Selain itu, perlu peningkatan promosi kehamilan sehat sejak masa prakonsepsi untuk mencegah kasus BBLR yang dapat berisiko terhadap morbiditas dan mortalitas anak serta dampak jangka panjang stunting yang merugikan hingga masa dewasa. Perlu dilakukan penelitian lanjut untuk program intervensi penatalaksanaan kasus stunting berdasarkan hasil temuan ini dengan meningkatkan promosi ASI dan pencegahan BBLR.

\section{SIMPULAN DAN SARAN}

Penelitian ini menemukan bahwa riwayat ASI eksklusif dan BBLR adalah faktor yang berpengaruh terhadap terjadinya stunting pada balita usia 2-5 tahun. Dengan demikian, perlu implementasi program intervensi pencegahan kasus stunting melalui promosi kehamilan sehat dan ASI eksklusif serta intervensi kuratif pada kasus stunting untuk mencegah morbiditas balita di Kabupaten Pesawaran.

\section{UCAPAN TERIMA KASIH}

Penulis menyampaikan ucapan terima kasih kepada Kementrian Riset dan Teknologi Pendidikan tinggi yang telah mendukung terlaksananya penelitian ini melalui program hibah dosen.

\section{Pernyataan konflik kepentingan}

Tidak ada konflik kepentingan dalam penelitian ini.

\section{RUJUKAN}

1. Aryastami NK, Shankar A, Kusumawardani N, Besral B, Jahari AB, Achadi E. Low birth weight was the most dominant predictor associated with stunting among children aged $12-23$ months in Indonesia. BMC Nutrition 2017;3:16. doi: 10.1186/s40795-017-0130-x

2. Kemenkes RI. Riset Kesehatan Dasar. Jakarta: Kemenkes RI; 2013.

3. Kemenkes RI. Hasil Pemantauan Status Gizi (psg) tahun 2017. Jakarta: Kemenkes RI; 2017.

4. Kemenkes RI. Hasil Pemantauan Status Gizi (PSG) tahun 2016. Jakarta: Kemenkes RI; 2016.

5. Kemenkes RI. Hasil Pemantauan Status Gizi (PSG) tahun 2015. Jakarta: Kemenkes RI; 2015.

6. Prawirohartono E, Nurdiati D, Hakimi M. Prognostic factors at birth for stunting at 24 months of age in rural Indonesia. Paediatrica Indonesiana [series online] 2016 [cited 2 Aug 2016];56(1):48-6. Available from: URL: https://paediatricaindonesiana.org/index.php/paediatricaindonesiana/article/view/79

7. Esfarjani F, Roustaee R, Mohammadi F, Esmaillzadeh A. Determinants of stunting in school-aged children of Tehran, Iran. Int J Prev Med 2013;4(2):173-9.

8. Dinas Kesehatan Provinsi Lampung. Profil kesehatan Provinsi Lampung tahun 2017. Lampung: Dinas Kesehatan Provinsi Lampung; 2017.

9. Cruz LMG, Azpeitia GG, Súarez DR, Rodríguez AS, Ferrer JFL, Serra-Majem L. Factors associated with stunting among children aged 0 to 59 months from the Central Region of Mozambique. Nutrient 2017;9(5). doi: 10.3390/nu9050491.

10. Kumar A, Singh Vk. A study of exclusive breastfeeding and its impact on nutritional status of child in EAG States. J Stat Appl Pro 2015;4(3):435-45. doi: 10.12785/jsap/040311

11. Danaei G, Andrews KG, Sudfeld CR, Fink G, McCoy DC, Fawzi WW, et al. Risk factors for childhood stunting in 137 developing countries: a comparative risk assessment analysis at global, regional, and country levels. PLoS Med. 2016;13(11):e1002164. doi: 10.1371/journal. pmed.1002164. 
12. Kemenkes RI. Buku kesehatan ibu dan anak. Jakarta: Kemenkes RI; 2015.

13. Kemenkes RI. Demographic and health survey 2012. Jakarta: Kemenkes RI; 2012.

14. Victora CG, Adair L, Fall C, Hallal PC, Martorell R, Maternal and Child Undernutrition Study Group, et al. Maternal and child undernutrition: consequences for adult health and human capital. Lancet 2008;371(9609):340-57. doi: 10.1016/S0140-6736(07)61692-4.

15. Cobayashi F, Augusto RA, Lourenço BH, Muniz PT, Cardoso MA. Factors associated with stunting and overweight in Amazonian children: a population-based, cross-sectional study. Public Health Nutr 2014;17(3):55160. doi: 10.1017/S1368980013000190

16. Ali Z, Saaka M, Adams A, Kamwininaang SK, Abizari AA. The effect of maternal and child factors on stunting, wasting and underweight among preschool children In Northern Ghana. BMC Nutrition 2017;3:31. doi: 10.1186/ s40795-017-0154-2

17. Visser J. The effect of childhood stunting on adult life [Thesis]. [series online] 2016 [cited 2 Aug 2017]. Available from: URL: https://pdfs.semanticscholar.org/ca37/ fa311e8752632244263515dcf027813560c7.pdf

18. Horta Bl, Victora Cg. Short-term effects of breastfeeding: a systematic review on the benefits of breastfeeding on diarrhoea and pneumonia mortality. World Heal Organ [series online] 2013;1-54. Available From: URL: https:// www.who.int/maternal_child_adolescent/documents/ breastfeeding_short_term_effects/en/

19. Horta BL, Victoria CG, WHO. Long-term effects of breastfeeding: a systematic review. [series online] 2013 [cited 2 Aug 2017]. Available from: URL: https://apps. who.int/iris/handle/10665/79198

20. Fenske N, Burns J, Hothorn T, Rehfuess Ea. Understanding child stunting in India: a comprehensive analysis of socio-economic, nutritional and environmental determinants using additive quantile regression. PLoS One 2013;8(11):e78692. doi: 10.1371/journal. pone.0078692

21. Harttgen K, Klasen S, Vollmer S. Economic growth and child undernutrition in Africa. Population and Development Review 2013;39(3):397-412. 